\title{
Karakterisasi Asap Cair Distilasi dan Terdistilasi Vakum dari Limbah Serasah Pinus
}

\author{
Wafa Karimatul Azmi, Ihak Sumardi*, Yoyo Suhaya \\ Teknologi Pasca Panen, Sekolah Ilmu dan Teknologi Hayati, Institut Teknologi Bandung, \\ Jl. Let. Jend. Purn. Dr. (HC) Mashudi No.1, Sayang, Jatinangor, Sumedang, Indonesia
}

Diterima : 22 September 2021, Revisi akhir : 25 Desember 2021, Disetujui terbit : 30 Desember 2021

\section{Characterization of Distilled and Vacuum Distilled Liquid Smoke from Pine Litter Waste}

\begin{abstract}
The solid waste of pine litter in the form of leaves, strobilus, and pine sawdust in the gondorukem and turpentine factories is still minimally utilized and causes environmental problems. However, the presence of cellulose, hemicellulose, and lignin content makes pine litter potential to be used as liquid smoke through the pyrolysis process. Liquid smoke has many benefits, including as an antiseptic and food preservative, but the characteristics of liquid smoke from pine litter are not yet known, so it requires further study. This research aims to determine the characteristics of smoke from pine litter waste, especially the composition of its chemical components, so the possibility for wider utilization can be known. The manufacture of liquid smoke is carried out through pyrolysis on pine litter waste, then given vacuum distillation treatment as a purification attempt. Tests on both samples using yield parameters, $\mathrm{pH}$, total acid value, color organoleptic properties, specific gravity, and analysis of chemical components using gas chromatography-mass spectrometry. The results showed that the yield of liquid smoke and charcoal from waste pine litter is low, but the yield of vacuum distilled liquid smoke is huge. The distilled liquid smoke had a darker color, lower $\mathrm{pH}$, higher total acid, and higher specific gravity than vacuum distilled liquid smoke. In general, the chemical components identified in both groups are divided into carbonyl, aryl alkyl ether, alkane, organic acids, and phenolic compounds. The content of phenolic compounds and furfural as the dominant compounds opens opportunities for use as wood preservatives, food preservatives, topical analgesics, antiseptics, fungicides, and nematocides.
\end{abstract}

Keywords: liquid smoke, pine litter waste, vacuum distillation, chemical compound, characterization

\begin{abstract}
Abstrak
Limbah padat serasah pinus berupa daun, strobilus, dan serbuk kayu pinus di pabrik gondorukem dan terpentin masih minim pemanfaatannya dan menimbulkan masalah lingkungan. Serasah pinus memiliki kandungan selulosa, hemiselulosa, dan lignin yang berpotensi untuk dimanfaatkan sebagai asap cair melalui proses pirolisis. Asap cair memiliki banyak manfaat, di antaranya sebagai bahan antiseptik dan pengawet makanan. Namun asap cair dari limbah serasah pinus masih belum diketahui karakteristiknya, sehingga membutuhkan pengkajian lebih lanjut. Penelitian ini dilakukan untuk mengetahui karakteristik asap cair dari limbah serasah pinus berdasarkan sifat fisik dan susunan komponen kimianya, sehingga dapat diketahui peluang pemanfaatannya secara lebih luas. Pembuatan asap cair dilakukan melalui proses pirolisis pada limbah serasah pinus, lalu diberikan variasi perlakuan distilasi vakum sebagai upaya purifikasi. Pengujian pada asap cair distilasi dan asap cair terdistilasi vakum menggunakan parameter rendemen, $\mathrm{pH}$, nilai total asam, sifat organoleptik warna, bobot jenis, dan analisis komponen kimia menggunakan gas chromatography-mass spectrometry. Hasil penelitian menunjukkan bahwa asap cair dari limbah serasah pinus distilasi memiliki warna yang lebih gelap, $\mathrm{pH}$ yang lebih rendah, total asam yang lebih banyak, dan bobot jenis yang lebih tinggi daripada asap cair terdistilasi vakum. Secara umum, komponen kimia yang teridentifikasi pada keduanya terbagi dalam kelompok karbonil, alkana, aril alkil eter, senyawa asam, dan senyawa fenolik. Asap cair distilasi mengandung beberapa senyawa dari kelompok terpena dan terpenoid, sedangkan asap cair distilasi vakum mengandung senyawa dari kelompok alkaloid. Kandungan senyawa fenolik dan furfural sebagai senyawa dominan membuka peluang pemanfaatan sebagai pengawet kayu, pengawet makanan, analgesik topikal, antiseptik, fungisida, dan nematosida.
\end{abstract}

Kata Kunci: asap cair, limbah serasah pinus, distilasi vakum, komponen kimia, karakterisasi 


\section{Pendahuluan}

Pinus merupakan salah satu jenis tanaman yang dapat tumbuh pada berbagai kondisi lingkungan dan kontur tanah. Tanaman pinus bahkan dapat tumbuh pada kontur tanah yang terjal, seperti jurang atau pegunungan (Kalensun, Wuntu and Kamu, 2012). Tanaman pinus jenis Pinus merkusii adalah spesies asli Sumatera yang mulai diperkenalkan dan ditanam di Pulau Jawa oleh Perum Perhutani pada tahun 1924. Saat ini, Pinus merkusii sudah ditanam secara luas di Pulau Jawa dengan jumlah yang melimpah dan pemanfaatan yang tinggi. Kayu Pinus merkusii sering dimanfaatkan sebagai bahan furnitur, kertas dan kayu gergajian, sedangkan getahnya biasa disadap sebagai bahan baku gondorukem dan terpentin (Sukarno et al., 2015).

Pengolahan getah pinus terbilang sangat tinggi, namun jumlah limbah yang dihasilkan juga tinggi, khususnya limbah padat. Salah satu contoh kasus nyata di Pabrik Gondorukem dan Terpentin (PGT) Sindangwangi, sekitar 15.000 ton getah pinus per tahunnya, dengan total rendemen produksi per tahunnya sekitar $87 \%$, sedangkan $13 \%$ lainnya terbagi atas $5 \%$ rendemen limbah serasah pinus dan $8 \%$ rendemen limbah air dan kotoran lainnya. Jumlah 5\% rendemen serasah pinus kurang lebih setara dengan 750 ton. Limbah serasah yang dihasilkan oleh PGT Sindangwangi umumnya ditumpuk pada tempat khusus. Namun saat jumlahnya sudah sangat banyak, area lain di sekitarnya juga akan ikut digunakan, sehingga menghabiskan banyak tempat. Apabila ditumpuk terlalu lama tanpa penanganan, limbah serasah pinus juga dapat mengotori lingkungan, menghambat mobilisasi, dan mengganggu kenyamanan lingkungan sekitar. Karenanya, masalah limbah serasah di PGT Sindangwangi perlu diatasi untuk meminimalisir masalah yang ditimbulkan atau lebih jauh lagi untuk memberi manfaat bagi industri lainnya.

Limbah serasah pinus diartikan sebagai daun, stobilus, dan serbuk kayu yang terlepas dari pohon pinus dan tercampur dengan resin pinus saat pengolahan. Serasah pinus merupakan bahan lignoselulosa atau komponen organik dengan kandungan selulosa, hemiselulosa, dan lignin (Theapparat, Chandumpai and Faroongsarng, 2018). Sedangkan resin pinus terbagi atas dua fraksi, yakni fraksi asam yang didominasi oleh kandungan methyl pallustric acid dan fraksi netral yang didominasi oleh $\Delta$-3-carene serta a-pinene (Wiyono, Tachibana and Tinambunan, 2006).

Asap cair adalah hasil dekomposisi biomassa berlignoselulosa melalui pemanasan suhu tinggi dengan terbatas oksigen yang dikondensasi (Ridhuan, Irawan and Inthifawzi, 2019), sehingga terbentuk senyawa asam, senyawa fenolik, furan, dan senyawa lainnya (Haji, 2013). Limbah serasah pinus memiliki kandungan selulosa, hemiselulosa, dan lignin sehingga berpotensi untuk dimanfaatkan sebagai asap cair melalui proses pirolisis. Asap cair diketahui memiliki banyak manfaat, di antaranya sebagai bahan pengawet makanan (Lingbeck et al., 2014), bahan antiseptik, antioksidan (Saloko et al., 2014), dan bahan koagulan (Vachlepi and Suwardin, 2015).

Sifat asap cair yang dihasilkan akan sangat bergantung dengan biomassa yang digunakan, sedangkan kualitasnya bergantung pada komposisi asam, tar, dan fenol, serta kemurnian senyawa kimia yang terkandung. Pemurnian yang umum dilakukan adalah proses sedimentasi dan distilasi, baik secara sederhana maupun beberapa tingkat. Sehingga dapat dihasilkan kualitas asap cair yang diinginkan bergantung dengan kebutuhannya (Rusydi, 2019).

Distilasi vakum merupakan proses pemisahan komponen yang melalui penguapan dan kondensasi yang didasari oleh penggunaan tekanan di bawah tekanan atmosfer, sehingga dapat menurunkan titik didih (Rahman et al., 2018). Distilasi vakum umumnya digunakan akibat titik didih senyawa yang akan dipisahkan terlalu tinggi atau sifat senyawa yang mudah teroksidasi. Penggunaan distilasi vakum juga dinilai menguntungkan karena lebih cepat daripada distilasi atmosfer dan tidak mengeluarkan limbah penguapan ke udara. Hal ini sangat penting apabila komponen yang dipisahkan mengandung senyawa yang berbahaya (Zha et al., 2019). Purifikasi asap cair dari limbah serasah pinus dengan distilasi vakum dinilai dapat meningkatkan kualitasnya, karena dapat memisahkan tar dan heavy-oil yang tidak diperlukan (de Souza Araújo et al., 2018).

Sifat dan kualitas asap cair dari limbah serasah pinus belum banyak diketahui. Oleh karena itu, penelitian ini bertujuan untuk menentukan karakteristik asap cair distilasi dan terdistilasi vakum dari limbah serasah pinus, baik dari sifat fisiknya maupun komposisi kimianya. Selain itu, penelitian ini juga dilakukan untuk menentukan peluang pemanfaatan asap cair limbah serasah 
pinus. Peluang pemanfaatan ditentukan dengan dasar karakteristik kimianya.

\section{Bahan dan Metode}

Alat yang digunakan pada penelitian ini adalah alat-alat gelas, Gas Cromatography-Mass Spectrometry (GC-MS) merk Agilent 19091S433, oven, penangas air, $\mathrm{pH}$ meter, piknometer, pirolisator, rotary vacuum evaporator merk Buchi R-215, dan timbangan. Pirolisator yang digunakan meliputi reaktor pembakaran, kondensor, dan pipa aliran, tetapi tidak dilengkapi pengatur suhu dan thermometer. Bahan yang baku yang digunakan pada penelitian ini adalah limbah serasah pinus yang didapatkan dari Pabrik Gondorukem dan Terpentin (PGT) Sindangwangi, Nagreg. Bahan lain yang digunakan dalam penelitian ini adalah alumunium foil, asam oksalat, aquades, etanol, indikator phenolphtalein, dan $\mathrm{NaOH}$ teknis. Analisis GC-MS dilakukan oleh Laboratorium LIPI Serpong. Rancangan penelitian yang dilakukan merupakan analisis perbandingan dua kelompok dengan satu faktor, yaitu dilakukan atau tidaknya distilasi vakum. Masing-masing perlakuan dilakukan dengan 3 kali pengulangan. Data dianalisis menggunakan paired sample T-test untuk membedakan antar group perlakuan melalui program SPSS versi 16 (Ghozali, 2006).

\section{Persiapan Sampel Asap Cair}

Sampel limbah serasah pinus dikeringkan terlebih dahulu selama 2 hari, tanpa terkena sinar matahari langsung. Sampel yang sudah kering, dengan kadar air 28,50\% kemudian ditimbang dan dimasukkan ke dalam reaktor pirolisis (drum yang tetutup dan diberi lubang asap dan cairan yang menetes ditampung, selama 24 jam) hingga penuh. Kemudian dilakukan pirolisis hingga pembakaran selesai seluruhnya dan dihasilkan asap cair yang telah terkondensasi yang ditampung dalam jerigen (Oktarina, Sumpono and Elvia, 2017). Sampel asap cair kemudian dibagi menjadi dua bagian, salah satu bagian menjadi sampel asap cair distilasi dan bagian lainnya didistilasi vakum. Distilasi vakum menggunakan rotary vacuum evaporator pada suhu $75-80^{\circ} \mathrm{C}$, tekanan $154-194$ mbar, dan rotasi $70 \mathrm{rpm}$ hingga teruapkan seluruhnya. Asap cair yang telah didistilasi kemudian dilakukan vakum disebut sampel asap cair terdistilasi vakum.

\section{Pembuatan Asap cair}

Pembuatan asap cair dimulai dengan memasukkan limbah serasah pinus ke dalam pirolisator, produk yang dihasilkan berupa arang dan asap cair. Asap cair yang dihasilkan kemudian dipisahkan sebagian untuk dilakukan distilasi vakum, sedangkan sebagian lainnya menjadi sampel asap cair serasah pinus distilasi. Asap cair yang telah didistilasi kemudian disebut sampel asap cair serasah pinus terdistilasi vakum (Gambar 1).

\section{Perhitungan Rendemen}

Rendemen yang dihasilkan dihitung sesuai fraksinya. Fraksi yang dihitung adalah rendemen asap cair, rendemen arang, dan rendemen asap cair yang telah didistilasi vakum. Penghitungan rendemen dapat dilakukan dengan menggunakan Persamaan 1.

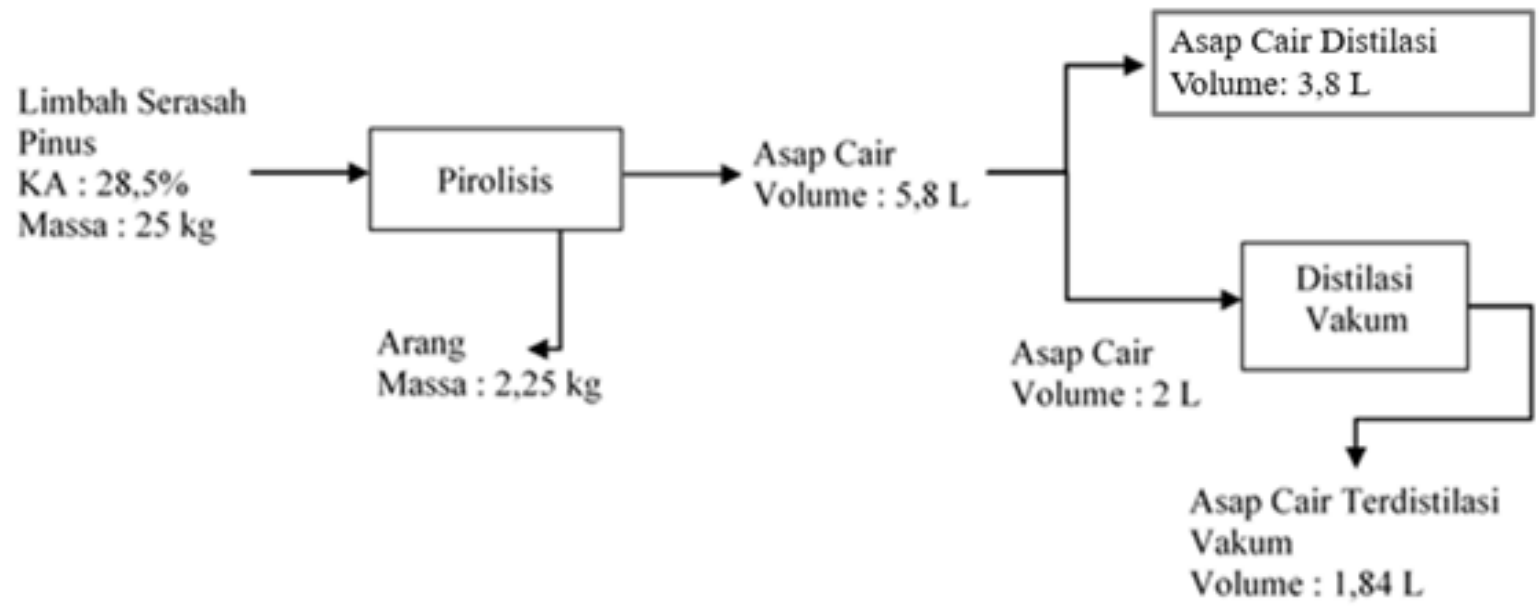

Gambar 1. Diagram aliran produk 
$\%$ Rendemen $=\frac{m_{o}}{m_{i}} \times 100 \%$

Keterangan :

$m_{o}$ adalah massa fraksi output $(\mathrm{g})$

$m_{i}$ adalah massa fraksi input $(\mathrm{g})$

\section{Pengujian Organoleptik Warna}

Sampel asap cair distilasi dan distilasi vakum disiapkan pada wadah transparan. Sampel dinilai warnanya dengan metode organoleptik yang dimodifikasi (Sari, Mahdie and Segah, 2015) oleh panelis sejumlah 20 orang. Penilaian dilakukan berdasarkan Tabel 1.

Tabel 1. Parameter penilaian uji organoleptik warna

\begin{tabular}{lc}
\hline \multicolumn{1}{c}{ Karakter warna } & Nilai \\
\hline Tidak berwarna & 1 \\
Kuning muda & 2 \\
Kuning kecoklatan & 3 \\
Coklat & 4 \\
Hitam & 5 \\
\hline
\end{tabular}

\section{Pengukuran Derajat Keasaman (pH)}

Sampel asap cair distilasi dan terdistilasi vakum sebanyak $20 \mathrm{~mL}$ diukur derajat keasaman menggunakan $\mathrm{pH}$ meter digital yang telah terkalibrasi. Pengukuran dilakukan dengan pengulangan sebanyak 3 kali untuk tiap sampel.

\section{Pengukuran Total Asam Tertitrasi (TAT)}

Asap cair distilasi dan terdistilasi vakum sebanyak $10 \mathrm{~mL}$ diencerkan menggunakan akuades hingga $100 \mathrm{~mL}$. Asap cair yang telah diencerkan kemudian diambil sebanyak $10 \mathrm{~mL}$ dan ditambahkan 2-3 tetes indikator phenolftalein 1\% (Aprilia et al., 2019). Larutan kemudian dititrasi menggunakan larutan $\mathrm{NaOH}$ $0,1 \mathrm{M}$ hingga titik akhir titrasi. Nilai total asam dinyatakan sebagai nilai total asam asetat yang dapat dihitung menggunakan Persamaan 2. Pengukuran dilakukan dengan pengulangan sebanyak 3 kali untuk tiap sampel.

$\% \mathrm{TAT}=\frac{\mathrm{V}_{1} \times \mathrm{M}_{1} \times \mathrm{Mr}_{2}}{V_{\text {sampel }} \times 1000} \times 10 \times 100 \%$
Keterangan :

$V$ adalah volume $\mathrm{NaOH}(\mathrm{mL})$

$V_{\text {sampel }}$ adalah volume sampel $(\mathrm{mL})$

$M_{1}$ adalah molaritas $\mathrm{NaOH}(\mathrm{M})$

$\mathrm{Mr}_{2}$ adalah massa molekul relatif asam asetat

\section{Pengukuran Bobot Jenis}

Pengukuran diawali dengan penimbangan piknometer kosong $25 \mathrm{~mL}$. Setelah itu, ditimbang piknometer berisi akuades $25 \mathrm{~mL}$ dan juga piknometer berisi sampel asap cair distilasi dan asap cair terdistilasi vakum masing-masing sebanyak $25 \mathrm{~mL}$ (Fachraniah, Fona and Rahmi, 2019). Penimbangan diulang sebanyak 3 kali dan dihitung nilai bobot jenis menggunakan Persamaan 3.

$$
\text { Bobot jenis }=\frac{\mathrm{B}_{s}-\mathrm{B}_{p}}{\mathrm{~B}_{a}-\mathrm{B}_{p}}
$$

Keterangan:

$\mathrm{B}_{p}$ adalah bobot piknometer kosong $(\mathrm{g})$

$\mathrm{B}_{a}^{p}$ adalah bobot piknometer berisi aquades $(\mathrm{g})$

$\mathrm{B}_{s}$ adalah bobot piknometer berisi sampel $(\mathrm{g})$

\section{Analisis GC-MS}

Analisis GC-MS dilakukan dengan menginjeksikan sampel yang telah disaring pada instrumen GC-MS. Volume injeksi sebanyak 1 $\mu \mathrm{L}$ pada suhu $40^{\circ} \mathrm{C}$. Holding time terjadi selama 1 menit dan suhu post run pada $300^{\circ} \mathrm{C}$.

\section{Hasil dan Pembahasan}

Nilai rendemen yang dihasilkan dari pirolisis limbah serasah pinus dihitung dengan prinsip perbandingan massa output dengan input dan dinyatakan dalam bentuk persentase (Tabel 2). Rendemen asap cair dan rendemen arang merupakan perbandingan output total massa asap cair dan output total massa arang yang dihasilkan dengan input total limbah serasah yang dipirolisis. Sedangkan rendemen distilat asap cair merupakan perbandingan output total massa asap cair terdistilasi vakum dengan input massa total asap cair yang didistilasi. Nilai rendemen komponen yang hilang tidak dapat dihitung karena kurangnya data kondisi operasi pirolisis

Nilai rendemen asap cair limbah serasah pinus $(23,25 \%)$ yang dihasilkan dari proses 
pirolisis limbah serasah pinus terbilang sedikit apabila dibandingkan dengan hasil pirolisis asap cair kayu nyamplung yang mencapai 34,17\% (Suaib, Yermia and Agustina, 2019). Hal ini dikarenakan komposisi kimia bahan yang juga berbeda. Semakin tinggi kandungan lignin dan selulosa pada bahan, maka jumlah asap cair yang dihasilkan juga semakin banyak (Wibowo, 2012). Hal ini dikarenakan dekomposisi lignin dapat melepaskan produk-produk volatil penyusun asap cair (Brebu and Vasile, 2010), sedangkan dekomposisi selulosa menghasilkan asam-asam organik dan fenol sebagai penyusun asap cair, serta uap air sebagai larutan utama pada asap cair (Rusydi, 2019). Rendahnya rendemen asap cair limbah serasah pinus juga dipengaruhi oleh kadar air bahan. Semakin rendah kadar air bahan, maka rendemen asap cair juga akan semakin rendah dikarenakan uap air yang dihasilkan saat pembakaran juga hanya sedikit (Pamori, Efendi and Restuhadi, 2015).

Rendemen arang yang dihasilkan dari pirolisis limbah serasah pinus (9\%) juga lebih rendah dari rendemen arang cangkang buah karet sebesar 33,15-49,78\% (Fadillah and Alfiarty, 2015). Hal ini utamanya disebabkan oleh kandungan kimia pada bahan dan kondisi pembakaran. Semakin tinggi suhu karbonisasi, maka semakin besar rendemen arang yang dihasilkan. Kandungan selulosa, hemiselulosa, dan lignin pada limbah serasah pinus lebih rendah karena dibandingkan kandungan pada serasah pinus segar karena beberapa bagian telah terurai oleh mikroorganisme di tanah akibat penumpukan dalam jangka waktu lama (Simanungkalit, 2006). Kondisi pembakaran saat pirolisis dengan oksigen terbatas menjadikan reaksi pembakaran tidak sempurna dan membentuk kecenderungan penguapan hasil dekomposisi biomassa, bukannya terjadi karbonisasi (Aisyah,
2019). Sedangkan rendemen distilat asap cair dari limbah serasah pinus terbilang tinggi dibandingkan hasil penelitian dari distilat asap cair biomassa lainnya. Distilasi vakum yang dilakukan berfungsi untuk menghilangkan senyawa-senyawa yang tak diinginkan seperti karbonil, PAH, dan tar, serta memurnikan kandungan kimia yang dibutuhkan (Pimenta et al., 2000). Tingginya rendemen distilat asap cair diduga terjadi karena senyawa pengotor asap cair sedikit dan asap cair yang lebih cepat teruapkan akibat kondisi operasi vakum.

\section{Organoleptik Warna}

Karakteristik organoleptik warna asap cair limbah serasah pinus diamati dengan penilaian oleh panelis berdasarkan skala yang ditentukan (Tabel 1). Berdasarkan pengujian, nilai organoleptik warna asap cair distilasi adalah 2,95 atau dapat diartikan mendekati warna kuning kecoklatan. Sementara itu, nilai organoleptik asap cair terdistilasi vakum adalah 1,07 atau mendekati tidak berwarna. Warna asap cair distilasi lebih gelap dan berbeda nyata dengan warna asap cair terdistilasi vakum, keduanya sudah memenuhi standar mutu asap cair dan standar mutu distilat asap cair Jepang (tak berwarna - kuning pucat) pada Tabel 3 (Yatagai, 2002). Warna asap cair limbah serasah pinus distilasi lebih gelap (warna kecoklatan) akibat pemanasan yang cukup tinggi pada tekanan yang rendah, sehingga minyak mengalami kerusakan sehingga terbentuk karbonil, Polisiklik Aromatik Hidrokarbon (PAH), dan tar yang terbentuk saat pirolisis. Sedangkan asap cair limbah serasah pinus terdistilasi vakum sudah mengalami proses purifikasi berupa distilasi vakum yang dapat menghilangkan karbonil, PAH, dan tar (de Souza Araújo et al., 2018).

Tabel 2. Nilai rendemen masing-masing produk

\begin{tabular}{|c|c|c|c|}
\hline Rendemen & Nilai & Literatur & Sumber \\
\hline Asap Cair & $23,25 \%$ & $\begin{array}{l}34,17 \% \\
\text { Asap cair kayu nyamplung }\end{array}$ & $\begin{array}{l}\text { Suaib, Yermia and Agustina } \\
\text { (2019) }\end{array}$ \\
\hline Arang & $9,00 \%$ & $\begin{array}{l}33,15-49,78 \% \\
\text { Arang cangkang buah karet }\end{array}$ & Fadillah and Alfiarty (2015) \\
\hline $\begin{array}{l}\text { Distilat Asap } \\
\text { Cair }\end{array}$ & $91,88 \%$ & $\begin{array}{l}86,23 \% \\
\text { Distilat asap cair tempurung kelapa }\end{array}$ & $\begin{array}{l}\text { Muhammad, Darmadji and } \\
\text { Pranoto (2011) }\end{array}$ \\
\hline
\end{tabular}




\section{Derajat Keasaman (pH)}

Derajat keasaman atau $\mathrm{pH}$ pada asap cair menentukan kualitas asap cair. Semakin rendah pH asap cair, maka kualitasnya makin baik karena memiliki kualitas memiliki ketahanan penyimpanan yang tinggi dan memiliki kemampuan preservasi yang lebih baik pula, utamanya pada preservasi makanan (Salamah and Jamilatun, 2017). Nilai pH pada asap cair dipengaruhi oleh komposisi kimia pada asap cair dan level dekomposisi bahan saat pirolisis (Lombok et al., 2014). Berdasarkan hasil pengujian (Tabel 3), $\mathrm{pH}$ asap cair distilasi bernilai 2,77 dan $\mathrm{pH}$ asap cair terdistilasi vakum yang bernilai 3,36 . Nilai $\mathrm{pH}$ asap cair distilasi lebih rendah dan berbeda nyata dibandingkan $\mathrm{pH}$ asap cair terdistilasi vakum, tetapi keduanya memenuhi standar mutu asap cair dan distilat asap cair Jepang. Hal ini dikarenakan terdapat oksidasi saat distilasi, sehingga kadar asam dalam asap cair berkurang dan suasana asam berkurang (Salamah and Jamilatun, 2017). Nilai derajat keasaman atau $\mathrm{pH}$ tersebut didasari prinsip perhitungan jumlah ion hydronium atau $\mathrm{H}_{3} \mathrm{O}^{+}$ pada sampel (Montazeri et al., 2013).

\section{Total Asam Tertitrasi (TAT)}

Nilai Total Asam Tertitrasi (TAT) menunjukkan konsentrasi asam organik pada suatu produk, biasanya diukur melalui titrasi menggunakan basa standar untuk netralisasi (Oliveira, Neves and Ballus, 2019). Hasil pengujian menunjukkan bahwa nilai TAT sampel asap cair distilasi dan terdistilasi vakum sangat rendah di bawah standar mutu yang ditetapkan dan tidak berbeda nyata (Tabel 3). Padahal terdapat perbedaan $\mathrm{pH}$ yang signifikan di antara keduanya dan nilai TAT berkaitan erat dengan nilai $\mathrm{pH}$ dengan nilai yang berbanding terbalik (Prastujati, Hilmi and Khirzin, 2018). Nilai TAT tidak selalu bisa memprediksi nilai $\mathrm{pH}$ karena perbedaan dasar pengukurannya (Tyl and Sadler, 2017). Nilai TAT berfokus pada kandungan asam dominan sampel dan sangat bergantung pada kemampuan alkali untuk mendisosiasi asam, sedangkan pengukuran $\mathrm{pH}$ didasari prinsip pengukuran jumlah ion hydronium dan merupakan fungsi gabungan asam dan basa konjugasinya (Brown et al., 2017). Sehingga nilai TAT sampel tidak selalu dapat menggambarkan $\mathrm{pH}$ sampel. Selain itu, perbedaan nilai TAT yang tidak signifikan dapat pula diartikan sebagai keberhasilan metode distilasi vakum untuk mencegah oksidasi berlebihan pada saat purifikasi (Fatimura, 2014).

\section{Bobot Jenis}

Bobot jenis pada asap cair sebetulnya tidak terlalu berkaitan dengan kualitas asap cair, tetapi berkaitan dengan komponen yang terkandung dalam asap cair. Nilai bobot jenis pada asap cair distilasi dan terdistilasi vakum terbilang sangat rendah dan tidak dapat memenuhi mutu asap cair dan distilat asap cair Jepang. Nilai keduanya tidak

Tabel 3. Karakteristik fisik asap cair distilasi dan terdistilasi vakum dari limbah serasah pinus

\begin{tabular}{lcccc}
\hline \multicolumn{1}{c}{ Parameter Uji } & $\begin{array}{c}\text { Hasil Uji Asap Cair } \\
\text { Distilasi }\end{array}$ & Mutu Asap Cair & $\begin{array}{c}\text { Hasil Uji } \\
\text { Asap Cair } \\
\text { Terdistilasi } \\
\text { Vakum }\end{array}$ & $\begin{array}{c}\text { Mutu Distilat } \\
\text { Asap Cair }\end{array}$ \\
\hline Organoleptik Warna & $\begin{array}{c}\text { Mendekati kuning } \\
\text { kecoklatan }\end{array}$ & $\begin{array}{c}\text { Kuning - Kuning } \\
\text { kecoklatan }\end{array}$ & $\begin{array}{c}1,07^{\mathrm{b}} \\
\text { Mendekati } \\
\text { tak berwarna }\end{array}$ & $\begin{array}{c}\text { Tak Berwarna - } \\
\text { Kuning Pucat }\end{array}$ \\
pH & $2,77^{\mathrm{b}}$ & $1,50-3,70$ & $3,36^{\mathrm{a}}$ & $1,30-3,70$ \\
$\begin{array}{l}\text { Total Asam Tertitrasi } \\
\text { (TAT) }\end{array}$ & $0,328 \%^{\mathrm{a}}$ & $1-18 \%$ & $0,234 \%^{\mathrm{a}}$ & $1-18 \%$ \\
Bobot Jenis $(\mathrm{g} / \mathrm{mL})$ & $1,00228896^{\mathrm{a}}$ & $>1,005$ & $1,00094238^{\mathrm{a}}$ & $>1.001$
\end{tabular}

Keterangan: huruf yang sama pada angka dalam tabel menunjukkan tidak berbeda nyata $(\mathrm{p} \leq 0,05)$

*Sumber: Yatagai (2002) 
berbeda nyata, meskipun bobot jenis asap cair distilasi sedikit lebih tinggi daripada asap cair terdistilasi vakum (Tabel 3). Hal ini dikarenakan adanya proses distilasi yang mengeliminasi keberadaan Sebagian senyawa kimia yang tidak terlalu diperlukan, seperti tar, karbonil, dan polisiklik aromatik hidrokarbon (PAH) (Idiawati et al., 2021). Nilai bobot jenis yang sangat rendah mendekati $1 \mathrm{~g} / \mathrm{mL}$ menandakan kandungan air yang tinggi pada asap cair dan komponen kimia yang rendah. Umumnya, kandungan air pada asap cair berkisar $80-90 \%$ (Theapparat, Chandumpai and Faroongsarng, 2018).

\section{Analisis Komponen Kimia Berdasarkan GC- MS}

Hasil analisis GC-MS mendeteksi sebanyak 27 senyawa kimia pada sampel asap cair distilasi dan 20 senyawa kimia pada sampel asap cair terdistilasi vakum (Tabel 4). Dari keseluruhan senyawa tersebut, pada sampel asap cair distilasi terdapat 2 senyawa yang tergolong dalam Polisiklik Aromatik Hidrokarbon (PAH), sedangkan pada sampel terdistilasi vakum hanya terdapat 1 senyawa. Meski begitu, fenol tidak digolongkan sebagai senyawa karsinogenik, melainkan senyawa toksik pada konsentrasi tertentu (Lyutyy et al., 2017). Fenol umum ditemukan pada makanan hasil olahan dan masih dapat ditoleransi oleh manusia asalkan tidak melebihi 317 ppm (Kumayanjati, Swastawati and Riyadi, 2013). Analisis GC-MS pada keduanya tidak menunjukkan keberadaan Benzo(a)pyrene sebagai senyawa PAH yang paling paling dihindari karena sangat karsinogenik (Saputra, Naswir and Suryadri, 2020). Secara umum, komposisi kimia asap cair distilasi terbagi dalam kelompok senyawa karbonil, aril alkil eter, alkana, senyawa asam, senyawa fenolik, serta terpena dan terpenoid. Sementara komposisi kimia sampel asap cair terdistilasi vakum terbagi dalam kelompok karbonil, aril alkil eter, alkana, alkaloid, senyawa asam, dan senyawa fenolik.

Senyawa paling dominan dari kedua sampel tersebut adalah furfural dan fenol. Furfural merupakan senyawa yang terbentuk dari dekomposisi selulosa dan hemiselulosa. Sedangkan fenol merupakan hasil dekomposisi selulosa, hemiselulosa, dan lignin. Furfural dan fenol memiliki peran penting pada rasa dan aroma yang terbentuk pada asap cair. Karakter sensorik yang dibentuk oleh furfural adalah aroma almond dan roti, serta rasa manis, berkayu, nutty, dan seperti roti Sementara fenol dideskripsikan secara sensorik dengan bau asap, pedas, manis, dan beraroma bakaran (Tegang et al., 2020).

Kedua sampel memiliki kelompok senyawa berbeda. Sampel asap cair distilasi memiliki kelompok terpena dan terpenoid yang tidak dimiliki oleh sampel asap cair terdistilasi vakum. Sementara itu, sampel asap cair terdistilasi vakum memiliki kelompok senyawa alkaloid yang juga tidak dimiliki oleh sampel asap cair distilasi. Hal ini dikarenakan terpena yang telah terbentuk melalui pirolisis dapat terdegradasi dengan adanya pemanasan, semakin tinggi suhu pemanasan maka tingkat degradasi juga semakin tinggi (Yang et al., 2007). Pembentukan alkaloid belum diketahui pasti penyebabnya, namun diduga karena adanya reaksi pembentukan dari gugus amino bebas dengan aldehida (Cinelli and Jones, 2021).

\section{Peluang Pemanfaatan}

Asap cair limbah serasah pinus terdistilasi vakum memiliki potensi untuk dimanfaatkan sebagai pengawet dan juga perasa asap pada makanan, karena tidak mengandung senyawa karsinogenik. Derajat keasamannya juga masih tergolong rendah sehingga dapat membantu mempertahankan sifat organoleptik pada makanan (Lombok et al., 2014). Kandungan fenol dan furfural yang dominan pada asap cair akan memberikan rasa dan aroma yang khas pada makanan (Tegang et al., 2020). Selain itu, keberadaan senyawa fenolik juga disebut dapat menghambat pembentukan senyawa Polisiklik Aromatik Hidrokarbon (PAH) lainnya pada saat pembuatan roti dan meningkatkan kualitasnya (Xu, Wang and Li, 2019). Penelitian juga menunjukkan potensi pemanfaatan asap cair terdistilasi sebagai analgesik topikal untuk pengobatan traumatic ulcer pada pasien diabetes akibat tingginya komposisi senyawa fenolik (Surboyo et al., 2019). Penggunaan asap cair ini meredakan inflamasi dan meningkatkan pembentukan kolagen, sehingga mempercepat penyembuhan.

Senyawa fenolik dan beberapa jenis senyawa aldehida dari kelompok furan bersifat antiseptik dan antioksidan. Selain itu, senyawa-senyawa tersebut juga dapat mengganggu integritas sel mikroba dan serangga, sehingga potensial 
Tabel 4. Hasil analisis komponen kimia menggunakan GC-MS

\begin{tabular}{|c|c|c|c|c|c|c|}
\hline \multirow{2}{*}{$\begin{array}{l}\text { Kelompok } \\
\text { senyawa }\end{array}$} & \multicolumn{2}{|l|}{ Distilasi } & \multirow[t]{2}{*}{$\mathrm{PAH}$} & \multicolumn{2}{|l|}{ Distilasi Vakum } & \multirow[t]{2}{*}{ PAH } \\
\hline & Senyawa & Area $\%$ & & Senyawa & Area $\%$ & \\
\hline \multirow{11}{*}{ Karbonil } & 3-Methyl-1,2-cyclopentanedione & 4,0425 & & 3-Methyl-1,2-cyclopentanedione & 2,6351 & \\
\hline & 2,3-Dimethyl-2-cyclopenten-1-one & 2,2016 & & $\begin{array}{l}\text { 2,3-Dimethyl-2-cyclopenten-1- } \\
\text { one }\end{array}$ & 2,458 & \\
\hline & 2-Methyl-2-cyclopenten-1-one & 2,6699 & & 2-Methyl-2-cyclopenten-1-one & 3,8374 & \\
\hline & 3-Methyl-2-cyclopenten-1-one & 3,4869 & & 3-Methyl-2-cyclopenten-1-one & 3,822 & \\
\hline & 5-Methyl-2-furancarboxaldehyde & 4,3991 & & 5-Methyl-2-furancarboxaldehyde & 5,2823 & \\
\hline & Furfural & 18,6013 & & Furfural & 22,1395 & \\
\hline & 1,8-Nonadien-3-ol & 1,9709 & & Acetone & 1,3397 & \\
\hline & 1,2-Ethanediol, diacetate & 2,2437 & & 1,2-Ethanediol, diacetate & 2,9821 & \\
\hline & $\begin{array}{l}\text { 2-Furanone, 2,5-dihydro-3,5- } \\
\text { dimethyl }\end{array}$ & 1,451 & & & & \\
\hline & 3-Pentanone, 2-methyl- & 2,3955 & & & & \\
\hline & 5-Methyl-1-hepten-4-ol & 1,6823 & & & & \\
\hline Total & & 45,1447 & & & 41,514 & \\
\hline \multirow{3}{*}{$\begin{array}{l}\text { Aril alkil } \\
\text { eter }\end{array}$} & Disulfide, di-tert-dodecyl & 0,908 & & Methane, chloromethoxy- & 1,5909 & \\
\hline & Pent-2-ynal & 2,6509 & & & & \\
\hline & $\begin{array}{l}\text { 1H-Imidazole, 4,5-dihydro-2- } \\
\text { methyl- }\end{array}$ & 5,1117 & & & & \\
\hline Total & & 8,6706 & & & 1,5909 & \\
\hline \multirow{4}{*}{ Alkana } & Hexadecane, 1-iodo- & 1,2966 & & Hexadecane, 1-iodo- & 1,0737 & \\
\hline & Pentacosane & 0,978 & & Hexane, 3,3,4-trimethyl- & 2,9479 & \\
\hline & Tetradecane, 1-iodo- & 0,9656 & & & & \\
\hline & Octane, 2-methyl- & 1,5101 & & & & \\
\hline Total & & 4,7503 & & & 4,0216 & \\
\hline Alkaloid & & & & 1-Methyl pyrrolidin-3-amine & 2,8566 & \\
\hline Total & & - & & & 2,8566 & \\
\hline \multirow{2}{*}{$\begin{array}{l}\text { Senyawa } \\
\text { asam }\end{array}$} & Butanoic acid, 3-methylbutyl ester & 2,6878 & & Sulfurous acid, hexyl nonyl ester & 0,9557 & \\
\hline & & & & $\begin{array}{l}\text { 3-Fluorobenzoic acid, } \\
\text { 4-methylpentyl ester }\end{array}$ & 4,4809 & \\
\hline Total & & 2,6878 & & & 5,4366 & \\
\hline \multirow{6}{*}{$\begin{array}{l}\text { Senyawa } \\
\text { fenolik }\end{array}$} & Phenol, 2-methyl- & 3,3065 & & Phenol, 2-methyl- & 3,7053 & \\
\hline & Creosol & 3,5549 & & Creosol & 4,2243 & \\
\hline & Phenol & 9,755 & Ya & Phenol & 12,0656 & Ya \\
\hline & Phenol, 2-methoxy- & 10,5515 & & Phenol, 2-methoxy- & 12,3474 & \\
\hline & Phenol, 3-methyl- & 5,9903 & & p-Cresol & 6,3924 & \\
\hline & & & & Creosol & 2,8631 & \\
\hline Total & & 33,1582 & & & 38,735 & \\
\hline \multirow{3}{*}{$\begin{array}{l}\text { Terpena } \\
\text { dan } \\
\text { terpenoid }\end{array}$} & endo-Borneol & 0,7023 & & & & \\
\hline & $\begin{array}{l}\text { Bicyclo[2.2.1]hept-2-ene, } \\
\text { 1,7,7-trimethyl- }\end{array}$ & 3,5625 & Ya & & & \\
\hline & $(+)$-2-Bornanone & 1,3235 & & & & \\
\hline Total & & 5,5883 & & & - & \\
\hline
\end{tabular}

Keterangan : Identifikasi polisiklik aromatik hidrokarbon (PAH) dilakukan melalui The NASA Ames PAH IR Spectroscopic Database 
digunakan sebagai senyawa anti-mikroba dan insektisida (Aisyah, 2019). Senyawa fenolik juga dapat mengganggu metabolisme serangga, merusak kutikula serangga, dan mengacaukan sistem saraf serangga (Aseptianova, Fitri Wijayanti and Nurina, 2017).

Furfural, sebagai senyawa paling dominan pada kedua sampel asap cair diketahui dapat digunakan sebagai pelarut organik, fungisida, dan nematosida. Namun, furfural sebaiknya dimurnikan dan diproduksi pula produk-produk turunannya karena nilai ekonominya yang potensial. Furfural biasa digunakan oleh industri baja, farmasi, pertanian, plastik, pengolahan kayu, dan industri kimia (Dalvand et al., 2018). Furfural juga diketahui dapat meningkatkan kualitas petrodiesel dan menghilangkan 81 senyawa yang tidak diperlukan pada petrodiesel (Ishak, Hassan and Ezeldin, 2017).

\section{Kesimpulan}

Pirolisis limbah serasah pinus memiliki rendemen asap cair dan arang yang rendah, tetapi distilatnya memiliki nilai rendemen yang tinggi. Karakteristik fisik sampel asap cair distilasi memiliki warna yang lebih gelap, $\mathrm{pH}$ yang lebih rendah, nilai total asam tertitrasi (TAT) yang lebih tinggi, dan nilai bobot jenis yang lebih tinggi daripada sampel asap cair terdistilasi vakum. Perbedaan nyata hanya ditemukan pada karakteristik warna dan $\mathrm{pH}$. Komponen kimia pada asap cair limbah serasah pinus distilasi terbagi atas kelompok senyawa karbonil, aril alkil eter, alkana, senyawa asam, senyawa fenolik, serta terpena dan terpenoid. Sedangkan komponen kimia sampel asap cair terdistilasi vakum terbagi pada kelompok senyawa karbonil, aril alkil eter, alkana, alkaloid, senyawa asam, dan senyawa fenolik. Asap cair terdistilasi vakum dapat dimanfaatkan sebagai pengawet makanan, perisa asap bagi makanan, dan analgesik topikal untuk traumatic ulcer. Kedua sampel asap cair dapat dimanfaatkan sebagai insektisida, antiseptik, nematosida, atau fungisida. Pemurnian furfural sebagai senyawa dominan dapat meningkatkan peluang pemanfaatan asap cair limbah serasah pinus.

\section{Ucapan Terima Kasih}

Penelitian ini dapat dilaksanakan dengan baik karena didukung oleh banyak pihak. Oleh karena itu, peneliti mengucapkan terima kasih atas fasilitas riset, dukungan ilmiah, serta teknis dari Laboratorium Kayu Institut Teknologi Bandung dan Laboratorium Karakterisasi Lanjut Serpong di Lembaga Ilmu Pengetahuan Indonesia.

\section{Kontribusi Penulis}

Ide, desain, dan rancangan percobaan dilakukan oleh Wafa Kaimatul Azmi, Ihak Sumardi, dan Yoyo Suhaya; percobaan dan perlakuan pengujian dilakukan oleh Wafa Karimatul Azmi; pengumpulan dan analisis data dilakukan oleh Wafa Karimatul Azmi; penulisan manuskrip oleh Wafa Karimatul Azmi; perbaikan dan finalisasi manuskrip.

\section{Daftar Pustaka}

Aisyah, I. (2019) Multimanfaat arang dan asap cair dari limbah biomasa. Deepublish.

Aprilia, D., Hermalia, S., Rahayu, R. and Destiana, I. D. (2019) 'Pengaruh perbedaan konsentrasi pisang sebagai prebiotik alami dan pektin terhadap karakteristik cocogurt', in Prosiding Industrial Research Workshop and National Seminar, pp. 41-46.

Aseptianova, A., Fitri Wijayanti, T. and Nurina, N. (2017) 'Efektifitas pemanfaatan tanaman sebagai insektisida elektrik untuk mengendalikan nyamuk penular penyakit DBD', Bioeksperimen: Jurnal Penelitian Biologi, 3(2), pp. 10-19. doi: 10.23917/ bioeksperimen.v3i2.5178.

Brebu, M. and Vasile, C. (2010) 'Thermal degradation of lignin -A Review', Cellulose Chemistry and Technology, 44, pp. 353-363.

Brown, T. L., LeMay, H., Bursten, B., Murphy, C., Woodward, P. and Stoltzfus, M. (2017) Chemistry: The Central Science. 14 ${ }^{\text {th }}$ Edition. Pearson.

Cinelli, M. A. and Jones, A. D. (2021) 'Alkaloids of the genus datura: review of a rich resource for natural product discovery', Molecules, 26(9), p. 2629. doi: 10.3390/ molecules26092629.

Dalvand, K., Rubin, J., Gunukula, S., Clayton Wheeler, M. and Hunt, G. (2018) 'Economics of biofuels: Market potential of furfural and its derivatives', Biomass and Bioenergy, 115, pp. 56-63. doi: 10.1016/j. biombioe.2018.04.005. 
Fachraniah, F., Fona, Z. and Rahmi, Z. (2019) 'Peningkatan kualitas asap cair dengan destilasi', Jurnal Jurusan Teknik Kimia Politeknik Negeri Lhokseumawe, 7(14), pp. $1-11$.

Fadillah, H. and Alfiarty, A. (2015) 'The Influence of pyrolysis temperature and time to the yield and quality of rubber fruit (Hevea brasiliensis) shell liquid smoke', Seminar Nasional Teknik Kimia Kejuangan, pp. B1.1-B1.7.

Fatimura, M. (2014) 'Tinjauan teoritis faktor faktor yang mempengaruhi operasi kolom destilasi', Jurnal Media Teknik, 11(1), pp. 23-31.

Ghozali, I. (2006) Aplikasi analisis multivariate dengan program SPSS. Badan Penerbit Universitas Diponegoro.

Haji, A. G. (2013) 'Komponen kimia asap cair hasil pirolisis limbah padat kelapa sawit', Jurnal Rekayasa Kimia \& Lingkungan, 9(3), p. 110. doi: 10.23955/rkl.v9i3.779.

Idiawati, N., Monica, G., Sofiana, M. S. J., Safitri, I. and Siregar, S. (2021) 'Characteristics and chemical compounds liquid smoke of mangrove stem bark waste from charcoal industry', Journal of Southwest Jiaotong University, 56(3), pp. 63-71. doi: 10.35741/ issn.0258-2724.56.3.6.

Ishak, C. Y., Hassan, E. A. and Ezeldin, M. (2017) 'Quality improvement of sudanese petrodiesel fuel by furfural', American Journal of Analytical Chemistry, 08(05), pp. 355-369. doi: 10.4236/ajac.2017.85027.

Kalensun, A. G., Wuntu, A. D. and Kamu, V. S. (2012) 'Isoterm adsorpsi toluena pada arang aktif stobilus pinus (Pinus merkusii)', Jurnal Ilmiah Sains, 12(2), pp. 100-104. doi: 10.35799/jis.12.2.2012.562.

Kumayanjati, B., Swastawati, F. and Riyadi, P. H. (2013) 'Karakteristik kualitas dan tingkat keamanan ikan pari (Himantura sp.) asap yang diolah dengan metode pengasapan berbeda', Jurnal Pengolahan dan Bioteknologi Hasil Perikanan, 2(2), pp. 174-184.

Lingbeck, J. M., Cordero, P., O'Bryan, C. A., Johnson, M. G., Ricke, S. C. and Crandall, P. G. (2014) 'Functionality of liquid smoke as an all-natural antimicrobial in food preservation', Meat Science, 97(2), pp. 197-206. doi: 10.1016/j. meatsci.2014.02.003.
Lombok, J. Z., Setiaji, B., Trisunaryanti, W. and Wijaya, K. (2014) 'Effect of pyrolysis temperature and distillation on character of coconut shell liquid smoke', in Proceeding of International Conference on Research, Implementation, and Education of Mathematics and Sciences. Yogyakarta State University, pp. 87-96.

Lyutyy, P., Bekhta, P., Ortynska, G. and Sedliacik, J. (2017) 'Formaldehyde, phenol and ammonia emissions from wood/recycled polyethylene composites', Acta Facultatis Xylologiae, 59(1), pp. 107-112. doi: 10.17423/afx.2017.59.1.10.

Montazeri, N., Oliveira, A. C. M., Himelbloom, B. H., Leigh, M. B. and Crapo, C. A. (2013) 'Chemical characterization of commercial liquid smoke products', Food Science \& Nutrition, 1(1), pp. 102-115. doi: 10.1002/ fsn3.9.

Muhammad, R. A., Darmadji, D. and Pranoto, Y. P. (2011) 'Pengaruh suhu distilasi dan tingkat kondensor terhadap sifat sensoris distilat asap cair', Jurnal Teknologi Hasil Pertanian, 4(2), pp. 104-102. doi: 10.20961/ JTHP.V0I0.13574.

Oktarina, D., Sumpono, S. and Elvia, R. (2017) 'Uji efektivitas asap cair cangkang buah Hevea braziliensis terhadap aktivitas bakteri Escherichia coli', Alotrop, 1(1), pp. 1-5. doi: 10.33369/atp.v1i1.2704.

Oliveira, W. da S., Neves, D. A. and Ballus, C. A. (2019) 'Mature chemical analysis methods for food chemical properties evaluation', in Evaluation Technologies for Food Quality. Elsevier, pp. 63-90. doi: 10.1016/B978-012-814217-2.00005-6.

Pamori, R., Efendi, R. and Restuhadi, F. (2015) 'Karakteristik asap cair dari proses pirolisis limbah sabut kelapa muda', $S A G U, 14(2)$, pp. 43-50. doi: 10.31258/sagu.v14i2.3009.

Pimenta, A. S., Bayona, J. M., García, M. T. and Solanas, A. M. (2000) 'Evaluation of acute toxicity and genotoxicity of liquid products from Eucaliptus grandis wood pyrolysis', Arch environ Contam TOxicol, 38, pp. 169175.

Prastujati, A. U., Hilmi, M. and Khirzin, M. H. (2018) 'Pengaruh konsentrasi starter terhadap kadar alkohol, $\mathrm{pH}$, dan total asam tertitrasi (TAT) whey kefir', Jurnal Ilmu Peternakan Terapan, 1(2), pp. 63-69. doi: 10.25047/jipt.v1i2.893. 
Rahman, S., Helleur, R., MacQuarrie, S., Papari, S. and Hawboldt, K. (2018) 'Upgrading and isolation of low molecular weight compounds from bark and softwood bio-oils through vacuum distillation', Separation and Purification Technology, 194, pp. 123129. doi: 10.1016/j.seppur.2017.11.033.

Ridhuan, K., Irawan, D. and Inthifawzi, R. (2019) 'Proses pembakaran pirolisis dengan jenis biomassa dan karakteristik asap cair yang dihasilkan', Jurnal Program Studi Teknik Mesin UM Metro TURBO, 8(1), pp. 69-78.

Rusydi, S. M. (2019) Pyrotechnology 4 in 1 : Prinsip dasar teknologi pirolisa biomassa. UNIMAL PRESS.

Salamah, S. and Jamilatun, S. (2017) 'Pemanfaatan asap cair food grade yang dimurnikan dengan arang aktif sebagai pengawet ikan nila', Eksergi, 14(2), p. 29. doi: 10.31315/e.v14i2.2027.

Saloko, S., Darmadji, P., Setiaji, B. and Pranoto, Y. (2014) 'Antioxidative and antimicrobial activities of liquid smoke nanocapsules using chitosan and maltodextrin and its application on tuna fish preservation', Food Bioscience, 7, pp. 71-79. doi: 10.1016/j.fbio.2014.05.008.

Saputra, R. Y., Naswir, M. and Suryadri, H. (2020) 'Perbandingan karakteristik asap cair pada berbagai grade dari pirolisis batubara', Jurnal Engineering, 2(2), pp. 96-108. doi: 10.22437/jurnalengineering.v2i2.11531.

Sari, N. M., Mahdie, M. F. and Segah, R. (2015) 'Rendemen arang sekam dan kualitas asap cair sekam padi', Jurnal Hutan Tropis, 3(3), pp. 260-266.

Simanungkalit, R. (2006) Pupuk organik dan pupuk hayati. Bogor: Balai Besar Litbang Sumberdaya Lahan Pertanian, Badan Penelitian, dan Pengembangan Pertanian.

de Souza Araújo, E., Pimenta, A. S., Feijó, F. M. C., Castro, R. V. O., Fasciotti, M., Monteiro, T. V. C. and de Lima, K. M. G. (2018) 'Antibacterial and antifungal activities of pyroligneous acid from wood of Eucalyptus urograndis and Mimosa tenuiflora', Journal of Applied Microbiology, 124(1), pp. 85-96. doi: 10.1111/jam.13626.

Suaib, N. F., Yermia, Y. and Agustina, A. (2019) 'Pembuatan dan analisis komponen kimia asap cair kayu gamal (Gliricidia sepium) hasil pemurnia dengan destilasi bertingkat', Jurnal Sains dan Teknologi Pangan, 4(1), pp. 1868-1878.
Sukarno, A., Hardiyanto, E. B., Marsoem, S. N. and Na'iem., M. (2015) 'Oleoresin production, tupentine yield, and components of Pinus merkusii from various Indonesian Provenance', Journal of Tropical Forest Science, 27(1), pp. 136-141.

Surboyo, M. D. C., Arundina, I., Rahayu, R. P., Mansur, D. and Bramantoro, T. (2019) 'Potential of distilled liquid smoke derived from coconut (Cocos nucifera L) shell for traumatic ulcer healing in diabetic rats', European Journal of Dentistry, 13(02), pp. 271-279. doi: 10.1055/s-0039-1693527.

Tegang, A. S., Mbougueng, P. D., Sachindra, N. M., Douanla Nodem, N. F. and Tatsadjieu Ngoune, L. (2020) 'Characterization of volatile compounds of liquid smoke flavourings from some tropical hardwoods', Scientific African, 8, p. e00443. doi: 10.1016/j.sciaf.2020.e00443.

Theapparat, Y., Chandumpai, A. and Faroongsarng, D. (2018) 'Physicochemistry and utilization of wood vinegar from carbonization of tropical biomass waste', in Tropical Forests - New Edition. InTech. doi: 10.5772/intechopen. 77380.

Tyl, C. and Sadler, G. D. (2017) 'pH and Titratable Acidity', in Nielsen, S. S. (eds) (ed.) Food Analysis. Food Science Text Series. Springer, Cham, pp. 389-406. doi: 10.1007/978-3-319-45776-5_22.

Vachlepi, A. and Suwardin, D. (2015) 'Characterization of iron metal corrosion in liquid smoke coagulant', Procedia Chemistry, 16, pp. 420-426. doi: 10.1016/j. proche.2015.12.073.

Wibowo, S. (2012) 'Karakteristik asap cair tempurung nyamplung', Jurnal Penelitian Hasil Hutan, 30(3), pp. 218-227. doi: 10.20886/jphh.2012.30.3.218-227.

Wiyono, B., Tachibana, S. and Tinambunan, D. (2006) 'Chemical compositions of pine resin, rosin, and turpentine oil from West Java', Indonesian Journal of Forestry Research, 3(1), pp. 7-17. doi: 10.20886/ ijfr.2006.3.1.7-17.

Xu, J., Wang, W. and Li, Y. (2019) 'Dough properties, bread quality, and associated interactions with added phenolic compounds: A review', Journal of Functional Foods, 52, pp. 629-639. doi: 10.1016/j.jff.2018.11.052. 
Yang, Y., Kayan, B., Bozer, N., Pate, B., Baker, C. and Gizir, A. M. (2007) 'Terpene degradation and extraction from basil and oregano leaves using subcritical water', Journal of Chromatography A, 1152(1-2), pp. 262267. doi: 10.1016/j.chroma.2006.11.037.

Yatagai, M. (2002) Utilization of charcoal and wood vinegar in Japan. Graduate School of Agricultural and Life Sciencies, University of Tokyo.
Zha, G., Yang, C., Wang, Y., Guo, X., Jiang, W. and Yang, B. (2019) 'New vacuum distillation technology for separating and recovering valuable metals from a high value-added waste', Separation and Purification Technology, 209, pp. 863-869. doi: 10.1016/j.seppur.2018.09.038. 